\title{
STRATEGIES TO IMPROVE EDUCATION QUALITY THROUGH FACILITIES AND INFRASTRUCTURES MANAGEMENT IN SINGKAWANG VOCATIONAL SCHOOL
}

\author{
Kornelius Tony \\ Universitas Terbuka, Pontianak, Indonesia \\ E-mail: korneliustony@yahoo.com
}

\begin{abstract}
The school is a social institution whose existence is part of the nation's social system which aims to produce capable, democratic, responsible, faithful, faithful, physically and spiritually healthy individuals, possessing knowledge and skills, having a steady and independent personality. To achieve these objectives, a strong curriculum is needed, both infrastructure and superstructure. This study aimed to reveal the strategy to improve the quality of education through the management of facilities and infrastructure in Singkawang 1 Vocational High School (SMK) with a focus on 1) Facilities and infrastructure planning at Singkawang State Vocational School, 2) The use of facilities and infrastructure in Singkawang Vocational School 1,3) Supervision of Facilities and Infrastructure at SMK Negeri 1 Singkawang, 4) Reporting on facilities and infrastructure at SMK Negeri 1 Singkawang, 5) Obstacles faced in facilities and infrastructure at SMK Negeri 1 Singkawang. The research method used is descriptive research with a qualitative approach. Data collected by in-depth interviews, participant observation, documentation and analyzed through data reduction, data presentation, conclusions or verification. Data reliability testing is done by extending the observation period, and triangulation and member checking. The results of the study concluded: 1) planning of facilities and infrastructure programs have been made by the student department to develop facilities in school activities. 2) The use of facilities and infrastructure is carried out in accordance with the learning needs by each teacher and regulated and monitored in an orderly manner, 3) Supervision of facilities and infrastructure has been carried out directly by the school principal, 4) Reporting has been carried out periodically by the student body to the principal school, 5) Constraints faced in facilities and infrastructure are financing both for procurement and maintenance. Based on the results of the study suggested the following things: 1) The principal is expected to optimize the supervision of all activities that have been planned so that the specified goals can be achieved. 2) Need to involve the community in the procurement of financing and maintenance of facilities and infrastructure. 3) Teachers, the administration is expected to be involved in the management of facilities and infrastructure.
\end{abstract}

Keywords: Strategy; Education Quality; Facilities Management; Infrastructure

\section{INTRODUCTION}

The school is a social institution whose existence is part of the nation's social system, which aims to produce capable, democratic, responsible, faithful, faithful, physically and spiritually healthy individuals, possessing knowledge and skills, having a steady and independent personality (Mursidi, 2010). To achieve these objectives, a strong curriculum is needed, both infrastructure and superstructure. This curriculum will later be used as a guide in carrying out all learning activities, especially interactions between educators and students in teaching and learning activities. Teachers as educators are required to be able to organize interesting and meaningful learning so that the achievements achieved can be in accordance with the targets set.
The more complete and adequate learning facilities owned by a school will facilitate teachers in carrying out their duties as education personnel. Similarly, the atmosphere during learning activities. Means of learning must be developed to support the teaching and learning process. Such as the availability of sufficient classrooms for the number of students and good condition, the availability of libraries, laboratories, facilities to support curriculum activities, and infrastructure and facilities for extracurricular and local content activities.

Given the importance of facilities and infrastructure in learning activities, students, teachers, and schools will be directly related. Learners will be more helped by the support of learning facilities and infrastructure. Not all students have a good level of intelligence so that the use of learning facilities and infrastructure will help students, especially 
those who have weaknesses in participating in learning activities (Rahayu, 2019). The support of facilities and infrastructure will help teachers. Learning activities will also be more varied, interesting and meaningful. While the school is obliged to be the party most responsible for the management of all activities carried out. In addition to providing, schools also maintain and maintain the facilities and infrastructure that they have (Prastyawan, 2016: 43).

Means are a medium or a tool for learning so that education runs effectively. School facilities are needed to balance physical development; in a healthy body, there is a healthy mind and mind. According to Jejen (2014: 228) states that "with adequate facilities, the school not only gave birth to prospective scientists, but also candidates for scholars, sportsmen, and artists." Because children are given the broadest opportunity to be themselves, the teacher reads and directs and trains students according to their talents. With adequate facilities and competent teachers, the training will run well and smoothly. Equipment and equipment are directly used and support the educational process, especially teaching and learning such as blackboards, markers, erasers, stationery, books and teaching media.

Educational infrastructure is a facility whose facilities do not directly support the course of an education and teaching process in an educational institution, such as buildings, classrooms, courtyards, school gardens, roads leading to schools, and so on. However, if the infrastructure is used for biology learning activities, the school garden will become an educational facility, according to Kompri 2 (2015: 233).

In relation to the management of school facilities and infrastructure, systematic and directed activities related to planning, organizing, implementing and reporting is a part of management functions. In relation to management, although it tends to lead to a particular focus, experts different views in defining management. Management contains an element of guiding direction and management of a group of people towards the achievement of general goals. Management and organization explained that the understanding of management is so wide that there is no consistent definition used by everyone (Kompri 1, 2015: 1). According to Bafadal (2008: 1) explains that "Management is the process of utilizing all resources to achieve the goals set." Meanwhile, according to Barnawi and Arifin (2015: 14) states management can be defined as working with people to determine to interpret to achieve organizational goals by carrying out the functions of planning, organizing, structuring, personnel or staffing, directing and leadership as well supervision. Thus, the management of facilities and infrastructure is a collaborative process of the efficient and efficient utilization of all educational facilities and infrastructure owned by schools (Baharudin \& Makin, 2010).

This study intends to explain the strategy to improve the quality of education through the management of facilities and infrastructure in the Vocational School of Vocational School. To further limit the scope of research so that the results are expected to be more measurable, the writer takes one study sample at the SMK level. In this study, the authors chose Singkawang State Vocational School 1 as the research location. It is based on facilities and infrastructure at SMK Negeri 1 Singkawang. In the last 5 (five) years, there has been a positive change compared to the previous 5 (five) years.

\section{MethodOLOGY}

The research method used is descriptive research with a qualitative approach. The location of the study was conducted at Singkawang State Vocational School. Data collected by in-depth interviews, participant observation, documentation, and analyzed through data reduction, data presentation, conclusions or verification. Data reliability testing is done by extending the observation period, and triangulation and member checking. The procedure in this study consisted of 3 stages:

\section{Pre-Research Stage}

Some activities were carried out before the researchers entered the field. Each of them are (1) compilation of the initial design of the study, (2) obtaining a research permit, (3) exploring the field and completing the research design, (4) selecting and interacting with subjects and informants, and (5) preparing assistive devices for activities field.

It should be noted, and researchers put interest and concern for the facts or symptoms of strategies to improve the quality of education through the management of facilities and infrastructure and its social consequences. A cursory observation was made long before the research design was prepared and submitted as a research topic. Armed with preliminary observations and literature review, researchers submitted research proposals on strategies to improve the quality of education through the management of facilities and infrastructure at SMK Negeri 1 Singkawang. The proposed proposal is consulted with a supervisor and will be held in a seminar by inviting colleagues and experts. Because it uses a qualitative approach, this research proposal is seen as tentative. Therefore seminar opportunities are used to capture criticism and suggestions, both on topics and research methods. Based on these criticisms and input, the researcher revised the research design and conducted a field assessment.

Field assessment is carried out with three techniques simultaneously and flexibly, namely (1) observation; the researcher directly observes the management of planning carried out by the school principal and other elements in the Vocational School 1 Singkawang environment, (2) interviews; researchers in-depth interviewed several informants, (3) document review; The researcher chooses and records relevant document data. Formulation of the problem and selection of more appropriate research methods are based on field assessment (grand tour observation). Throughout the fieldwork, of course, the focus of attention and techniques continued to experience sharpening and adjustment.

\section{Field Activity Stage}

In the implementation of this research, changes and improvements occurred. Not only concerns the focus of research, but also on the research method. The concept of the sample in this study is related to selecting informants or 
specific social situations that can provide steady, correct and trusted information about the elements of the research's focus. The selection of informants follows the snowball sampling pattern. If the introduction and social interaction with the informant were successful, then ask the person who else is known or indirectly mentioned by him. In determining the amount and time of interacting with data sources, researchers use the sampling concept recommended by Lincoln and Guba in Sugiyono (2009: 54), namely maximum variation sampling to document unique variations. Researchers will stop the data collection if no new physical body is found from the data source. With this concept, the number of data sources is not a primary concern, but rather the completeness of information acquisition with existing diversity. Not yet ascertained all the informants from the leadership provide the necessary data. Because the informant is a source of data that were interviewed in-depth. Each is four elements of leadership, three educators and one administrative staff. Because the main data of this study were obtained based on interactions with informants in a natural setting, some equipment was prepared to make things easier, such as (1) stationery, (2) interview guidelines and android Samsung type A5 recording devices and photos using the Samsung Galaxy Tab android camera S, including field note sheet. This equipment is used if it does not interfere with the reasonableness of social interaction.

By interview, the researcher tries to obtain information by meeting face-to-face physically and answering questions with informants. With this technique, the researcher acts as well as a data collection tool. During the interview, the researcher will also examine the behavior of the informant in answering questions with researchers always trying to take advantage of opportunities and the most appropriate places to do interviews.

\section{Post-Field Stage}

After each field research activity has been completed, then all findings or data obtained are carried out triangulated, namely testing credibility as checking data from various sources, methods and times (Wiersma, 1986) including data processing, data reduction, data selection, grouping, and presenting data into patterns and consultations, determining themes, analyzing themes and completeness of data and consulting, testing the validity of data based on data and consultation groups, drafting reports and consulting designs, preparing research and consultation reports, test results (thesis examinations), thesis improvements and consultations, report submission.

\section{RESULTS AND DISCUSSION}

1. Facilities and infrastructure planning at SMK 1 Singkawang

Based on the results of interviews and documentation shows a tendency that facilities and infrastructure planning activities at SMK Negeri 1 Singkawang have been carried out by analyzing what subjects need facilities in relation to learning activities. To develop a school principal's plan together with the head of the expertise program and the field of study teacher conducts details of the infrastructure needed by the school. These details concern the characteristics, types of infrastructure facilities, level of needs, quantity, types, price specifications including constraints in the procurement of infrastructure.

2. Use of Facilities and Infrastructure of SMK Negeri 1 Singkawang

Based on the results of interviews and documentation shows a tendency that the use of facilities and infrastructure in SMK 1 Singkawang is adjusted to the needs of the teaching and learning process and the practice of expertise in each department. The use of educational facilities in the form of teaching aids is used to demonstrate particular objects or materials by the teacher. For educational infrastructure in the form of buildings and other supporting buildings used in accordance with their respective functions. The classroom is used as a place for learning with a maximum capacity of one class is 36 students. A practice room or workshop is used as a place to test student skills in a particular expertise program. For other supporting infrastructure such as the computer laboratory room used for the practice of computer subjects (KKPI), the multimedia room is used as a place for practical examinations or performance of students during semester exams or final school exams. For the spiritual needs of students, there is a small mosque that is used for worship for those who are Muslims. The multipurpose room is used as a school meeting room with students or with students' parents.

3. Supervision of Facilities and Infrastructure at SMK Negeri 1 Singkawang.

Based on the results of interviews and documentation shows a tendency that the supervision of facilities and infrastructure at SMK Negeri 1 Singkawang has been carried out by the school. Supervision of facilities and infrastructure is carried out jointly by the teacher and head of the laboratory or head of the workshop. This supervision is carried out at the time of use of the facilities and infrastructure and is periodically submitted to the deputy head of the infrastructure section. This supervision contains aspects including data on the quantities and conditions of goods that are fit to be used, damaged, or lost. In addition to involving the teacher and the head of the laboratory/workshop, the supervision technique for the use of facilities/infrastructure, the school also places CCTV equipment to supervise every facility and infrastructure used especially during student learning practices and at certain times when the school is quiet or after learning.

4. Reporting Facilities and Infrastructure at SMK 1 Singkawang

Based on the results of interviews and documentation shows a tendency that reporting facilities and infrastructure in SMK Negeri 1 has been carried out in the form of internal and external reports. Internal reports in the form of reports on the conditions of school facilities and infrastructure by the deputy head of facilities and infrastructure to the school principal. The purpose of this internal reporting is to evaluate and recommend the facilities and infrastructure that need to get a specific follow-up related to re-procurement, repairs, and replacements. Internal reports are conducted every six 
months. External reports are carried out once a year by compiling a report on the state of assets of school facilities and infrastructure and sending the results of the report to the regional assets of the Department of Education and Culture of West Kalimantan Province.

5. Obstacles in Facilities and Infrastructure at SMK Negeri 1 Singkawang

Based on the results of interviews and observations showed a tendency that the constraints in facilities and infrastructure in SMK Negeri 1 include financing, maintenance, and storage. Barriers to funding and maintenance are more likely to be sources of school funding that are minimal and limited. These conditions cause difficulties for schools in fulfilling student learning facilities and infrastructure. For storage is more due to the capacity of the school warehouse that has exceeded the capacity that has an impact on facilities and infrastructure that are damaged and unfit for use in other places that are not school sheds.

\section{CONCLUSION AND SUGGESTION}

\section{A. Conclusions}

Based on the research findings and discussion of results in the previous section, the strategy to improve the quality of education through the management of facilities and infrastructure in Singkawang 1 Vocational High School (SMK) can be concluded:

1. Facilities and Infrastructure Planning at Singkawang 1 Vocational School has been carried out by analyzing what subjects need facilities in relation to learning activities.

2. The use of facilities and infrastructure in SMK Negeri 1 Singkawang has been adjusted to the needs in the teaching and learning process and the practice of expertise in each department.

3. Supervision of facilities and infrastructure in SMK 1 Singkawang has been carried out by the school. Supervision of facilities and infrastructure is carried out jointly by the teacher and head of the laboratory or head of the workshop.

4. Reporting of facilities and infrastructure at SMK 1 Singkawang has been carried out in the form of internal and external reports. Internal report to the principal. External report to the regional assets section of the Department of Education and Culture of West Kalimantan Province.

5. Barriers to facilities and infrastructure in Singkawang State Vocational School 1 include financing, maintenance, and storage. Barriers to funding and maintenance are more likely to be sources of school funding that are minimal and limited. For more storage due to the capacity of school warehouses that have exceeded capacity.

\section{B. Suggestion}

In accordance with the research findings, the problem of the results and conclusions conveyed above, then some suggestions that need to be submitted are related to the Management of Infrastructure Activities of Practical
Activities to Improve the Quality of Education in Singkawang 1 Vocational High School (SMK). Principals need to involve all school residents in arrange infrastructure planning so that implementation, monitoring, and reporting can be carried out to the maximum.

\section{REFERENCES}

Baharudin \& Moh. Makin. (2010). Manajemen Pendidikan Islam Transformasi Menuju Sekolah/Madrasah Unggul. Yogyakarta: UIN-Maliki Press.

Danim Sudarwan (2009). Kepemimpinan pendidikan, kepemimpinan jenius, etika, perilaku motivasional dan mitos, Bandung: Alfabeta.

Mursidi, Ali. (2010). Pengelolaan Supervisi Pembelajaran di SMP 3 Cepu. Tesis. Universitas Muhammadiyah Surakarta.

Peraturan Pemerintah Nomor 19 tahun 2005 tentang Standar Nasional Pendidikan.

Prastyawan, P. (2016). Manajemen Sarana dan Prasarana Pendidikan. Al Hikmah: Jurnal Studi Keislaman, 6(1).

Rahayu, S. (2019). Manajemen Sarana dan Prasarana Pendidikan.

Rusdiana (2016). Pengembangan Organisasi Lembaga Pendidikan. Bandung. Pustaka Setia

Sugiyono (2014). Memahami Penelitian Kualitatif. Bandung: Alfabeta.

Supratikno Hendrawan (2006). Manajemen kinerja untuk menciptakan keunggulan bersaing. Yogyakarta: Graha ilmu, cetakan ke-1.

Wibowo (2011). Manajemen kinerja. Jakarta: Raja Press.

Wiersma, W. (1986). Research Methods in Education: An Introduction. Massachusetts: Allyn and Bacon, Inc. 